\title{
Grazing Deferment Effects on Forage Diet Quality and Ewe Performance Following Summer Rangeland Fire
}

\author{
Richard C. Waterman ${ }^{1}$ and Lance T. Vermeire ${ }^{2}$ \\ Authors are ${ }^{1}$ Research Animal Scientist and ${ }^{2}$ Rangeland Ecologist, US Department of Agriculture, Agricultural Research Service, Fort Keogh Livestock \\ and Range Research Laboratory, Miles City, MT 59301, USA.
}

\begin{abstract}
Complete rest or grazing deferment is a general recommendation to encourage vegetative recovery following fire in the western United States. However, effects of grazing deferments on animal performance have not been determined. Prescribed fires were individually applied to nine separate, 1.5-ha pastures each year (2006 and 2007) for a total of 18 pastures. Grazing was deferred until spring (16 May), early summer (19 June), or late summer (1 August) the growing season after fire. At the end of each deferment, a 70-d (2007) or 41-d (2008) grazing period was initiated. Stocking rates were consistent between treatments within year, but were adjusted between years to achieve the targeted residual biomass of approximately $300 \mathrm{~kg} \cdot \mathrm{ha}^{-1}$. Diet quality was assessed approximately every $15 \mathrm{~d}$ throughout each grazing period (three pastures $\cdot$ period $^{-1}$ ) via collection of rumen extrusa throughout the 2-yr study. Ewe body weight was measured on and off-test for each grazing period. Diet extrusa samples for in vitro organic matter disappearance was less $(P=0.03)$ for late summer than early summer grazing periods and equal to the spring period (62.9, 64.6, and $61.0 \pm 0.90 \%$, respectively for spring, early summer, and late summer grazing periods). In vitro neutral detergent fiber disappearance decreased $(P=0.01)$ by 10.6 percentage units from early grazing to late grazing period in 2007 , whereas no differences were observed in 2008. Ewe average daily gain did not differ between spring and early summer grazing periods and were greater $(P=0.03)$ than the negligible body weight gains of the late summer grazing period. Total gain was $10.9 \mathrm{~kg} \cdot \mathrm{ha}{ }^{-1}$ greater in 2008, and a quadratic response was measured for grazing period in 2007. Results indicate that deferment until early summer may be preferable so that stocking rates can be more accurately determined and animal performance is not diminished.
\end{abstract}

\section{Resumen}

El descanso o diferimiento del pastoreo es una recomendación común para fomentar la recuperación vegetativa después de la aplicación de fuego en el oeste de Estados Unidos. Sin embargo, no se han determinado los efectos del diferimiento de pastoreo en la performance animal. Se aplicaron quemas prescriptas individualmente a 9 potreros de 1.5 - ha cada año (2006 y 2007 ) sumando un total de 18 pasturas. El pastoreo se difirió hasta la primavera (16 de mayo), principios de verano (19 de junio), o a finales del verano (1 de agosto) de la temporada de crecimiento posterior a la quema. Al final de cada diferimiento, se inició un período de pastoreo de 70-d (2007) o 41-d (2008). La carga animal fue consistente entre los tratamientos dentro de cada año, pero fueron ajustadas entre años para lograr una biomasa residual de aproximadamente $300 \mathrm{~kg} \cdot \mathrm{ha}^{-1}$. La calidad de la dieta se evaluó aproximadamente cada $15 \mathrm{~d}$ a lo largo de cada período de pastoreo ( 3 potreros $\cdot$ período ${ }^{-1}$ ) a través de la recolección de extrusa ruminal durante los dos años del estudio. El peso corporal de las ovejas (PC) fue medido dentro y fuera de la prueba para cada período de pastoreo. Las desaparición de la materia orgánica in vitro de las muestras de extrusa ruminal fue menor $(P=0.03)$ para el período de pastoreo de finales de verano comparado con el de comienzos de verano e igual al período de primavera $(62.9,64.6$ y $61.0 \pm 0.90 \%$, para la primavera, principios de verano y finales del verano, respectivamente). La desaparición in vitro de fibra detergente neutro disminuyó $(P=0.01)$ en 10,6 unidades porcentuales desde comienzos a finales del período pastoreo en 2007 , mientras que no se observaron diferencias en 2008. El promedio de ganancia diaria de las ovejas en los períodos de pastoreo de primavera y comienzos del verano no fue diferente pero fue mayor $(P=0.03)$ que las ganancias de peso de cuerpo despreciables obtenidos durante el pastoreo de finales de verano. La ganancia de peso total fue mayor en $10.9 \mathrm{~kg} \cdot \mathrm{ha}^{-1}$ en 2008 y una se detectó una respuesta cuadrática al período de pastoreo en 2007. Los resultados indican que el diferimiento hasta principios del verano puede ser preferible para poder determinar la carga animal con más exactitud y para que el rendimiento animal no se vea disminuido.

Key Words: body weight gain, deferred grazing, grazing management, postfire grazing, summer burn

US Department of Agriculture, Agricultural Research Service (USDA-ARS), Northern Plains Area, is an equal opportunity/affirmative action employer. All agency services are available without discrimination. This research was conducted under a cooperative agreement between USDAARS and the Montana Agriculture Experiment Station. Mention of a proprietary product does not constitute a guarantee or warranty of the product by USDA, Montana Agriculture Experiment Station, or the authors and does not imply its approval to the exclusion of other products that also may be suitable.

Correspondence: Richard C. Waterman, US Department of Agriculture, Agricultural Research Service, Fort Keogh Livestock and Range Research Laboratory, Miles City, MT 59301, USA. Email: richard.waterman@ars.usda.gov

Manuscript received 14 October 2009; manuscript accepted 18 September 2010.

\section{INTRODUCTION}

Historically, rangeland fires in the Northern Great Plains occurred less than $35 \mathrm{yr}$ apart (Schmidt et al. 2002). Active fire suppression has disrupted the historic fire regime and lengthened fire return intervals primarily by reducing the areal extent of wildfires. Still, the majority of wildfires in the western United States occur during July and August (Higgins 1984; Westerling et al. 2003). Research on summer fire effects is limited, but early studies in the Northern Great Plains indicated 
fire reduced standing crop for three or more years (Clarke et al. 1943; Coupland 1973) and caused at least a short-term reduction in soil moisture (Dejong and MacDonald 1975). Clarke et al. (1943) further suggested that plant recovery was delayed by grazing. Consequently, land management agencies traditionally have favored multiple-year deferments (minimum $2 \mathrm{yr})$ prior to allowing domestic livestock to graze burned rangelands.

Recently, a more methodical approach has been implemented using site monitoring to aid the decision of when grazing can recommence (Bureau of Land Management 2007). Research documenting the association between livestock production and diet quality on semiarid rangeland the year following summer fire is lacking. Deferment of grazing until the later part of the growing season is believed to reduce plant stress (Vallentine 1990) and may favor postfire recovery. However, a tradeoff in animal performance may be expected as weight gain has been shown to decrease on nonburned Northern Great Plains rangeland as summer advances (Heitschmidt et al. 1993; Grings et al. 2004). Reduced animal performance is likely driven by hot ambient temperatures during summer as well as decreasing forage quality concurrent with increasing plant tissue age. Although seasonal temperature and plant tissue age are expected to be key factors on burned sites, three expected differences in seasonal forage quality dynamics may moderate seasonal declines in animal performance observed on nonburned rangeland. First, fire often increases grass nitrogen content (Daubenmire 1968; Augustine and Milchunas 2009). Second, combustion of standing dead material ensures that average available forage is younger on a recently burned site than nonburned sites. Finally, fire has been observed to change the timing of plant development within a growing season (White and Currie 1983). Each of these factors could alter periods of adequate nutrient supply relative to nonburned sites. Quantifying the ramifications of postfire grazing strategies for plant communities and livestock production are crucial to developing ecologically and economically sustainable management policies.

Objectives of this research were to determine grazing deferment effects on ewe diet quality and body weight (BW) change following summer fire on semi-arid rangeland. We hypothesized that ewe diet quality and weight gain would be greatest with spring use, least with late summer use, and intermediate with early summer use because of increasing age of forage and decreasing diet quality as the growing season progressed.

\section{METHODS AND MATERIALS}

\section{Study Area}

The study site was located in southeastern Montana at the Fort Keogh Livestock and Range Research Laboratory (LARRL), approximately $1.6 \mathrm{~km}$ west of Miles City, Montana (lat $46^{\circ} 22^{\prime} \mathrm{N}$, long $\left.105^{\circ} 5^{\prime} \mathrm{W}\right)$. The LARRL Institutional Animal Care and Use Committee approved all animal handling and experimental procedures used in the present study (no. 1011061). The LARRL encompasses 22500 ha of Northern Great Plains rangeland and has an average elevation of $730 \mathrm{~m}$, which includes rolling hills and barren land set apart by roughly eroded ridges, peaks, and mesas with small intersecting streams that seasonally drain into large permanent rivers meandering through broad, nearly level valleys. Experimental pastures were on a silty ecological site, dominated by perennial cool-season grasses. The most abundant graminoids prior to treatment were western wheatgrass (Pascopyrum smithii [Rydb.] A. Löve, 27\%), needle-and-thread (Hesperostipa comata [Trin. \& Rupr.] Barkworth, 17\%), threadleaf sedge (Carex filifolia Nutt., 15\%), and blue grama (Boutelona gracilis [Willd. Ex Kunth] Lag. Ex Griffiths, 12\%). Fringed sage (Artemisia frigida Willd.) and pricklypear cactus (Opuntia polyacantha Haw.) were frequent. Fringed sage comprised less than $3 \%$ of the biomass. All forbs combined were generally less than $8 \%$ of the biomass. Average current-year forage production for the site is $930 \mathrm{~kg} \cdot \mathrm{ha}^{-1}$ with near-average spring precipitation, based on a 14-yr record from an adjacent nongrazed pasture.

Average daily temperatures range from $-10^{\circ} \mathrm{C}$ in January to $24^{\circ} \mathrm{C}$ in July with daily maximum temperatures occasionally exceeding $37^{\circ} \mathrm{C}$ during summer and daily minimums occasionally dropping below $-40^{\circ} \mathrm{C}$ during winter. Average annual precipitation is $340 \mathrm{~mm}$ with the majority of precipitation occurring from April through September from convectional thunderstorms (Fig. 1). Precipitation and temperature information were obtained from Western Regional Climate Center (WRCC 2009).

\section{Treatments and Management}

Prescribed fires were conducted in 2 yr beginning in 2006, when initial pastures were burned, and 2007, when the second replication of pastures were burned during late summer. Burning was individually applied to nine separate, 1.5-ha pastures each year for a total of 18 pastures. Grazing was deferred until spring (16 May), early summer (19 June), or late summer (1 August) the growing season after fire. At the end of each deferment, a 70-d grazing trial (2007) or 41-d grazing trial (2008) was initiated. Spring grazing was initiated on schedule in 2008, but after $2 \mathrm{wk}$, ewes were removed from pastures for 2 wk because of delayed plant growth (visual observation; Fig. 2). All mature white-face crossbred ewes in experimental pastures had ad libitum access to water and were randomly allotted by weight to treatment and pasture (12 ewes ·pasture $^{-1}$ in 2007 and 10 ewes $\cdot$ pasture $^{-1}$ in 2008, which included two ruminally cannulated ewes in each pasture) with stocking rates of 60.1 animal unit day (AUD) $\cdot \mathrm{ha}^{-1}$ in 2007 and 30.6 AUD $\cdot \mathrm{ha}^{-1}$ in 2008 (9.08 kg dry matter [DM] intake $\left.\cdot \mathrm{AUD}^{-1}\right)$. Stocking rates were consistent between treatments within year, but were adjusted between years to achieve the targeted residual biomass of approximately $300 \mathrm{~kg} \cdot \mathrm{ha}^{-1}$. The ruminally cannulated ewes were pastured with the noncannulated ewes throughout grazing periods. Ruminally cannulated ewes in the May grazing period were subsequently used in the late summer grazing period. Heavy utilization was prescribed to evaluate deferment effects in a concurrent study on plant community response to grazing following summer fire. Ewe BW was measured to the nearest $0.5 \mathrm{~kg}$ at the beginning and end of each grazing trial following a 12 -h restriction from feed and water. Prior to grazing, eight $2 \times 1 \mathrm{~m}$ cages were randomly placed within each pasture to exclude sheep for utilization estimates. Grasses, forbs, and palatable shrubs were clipped to 


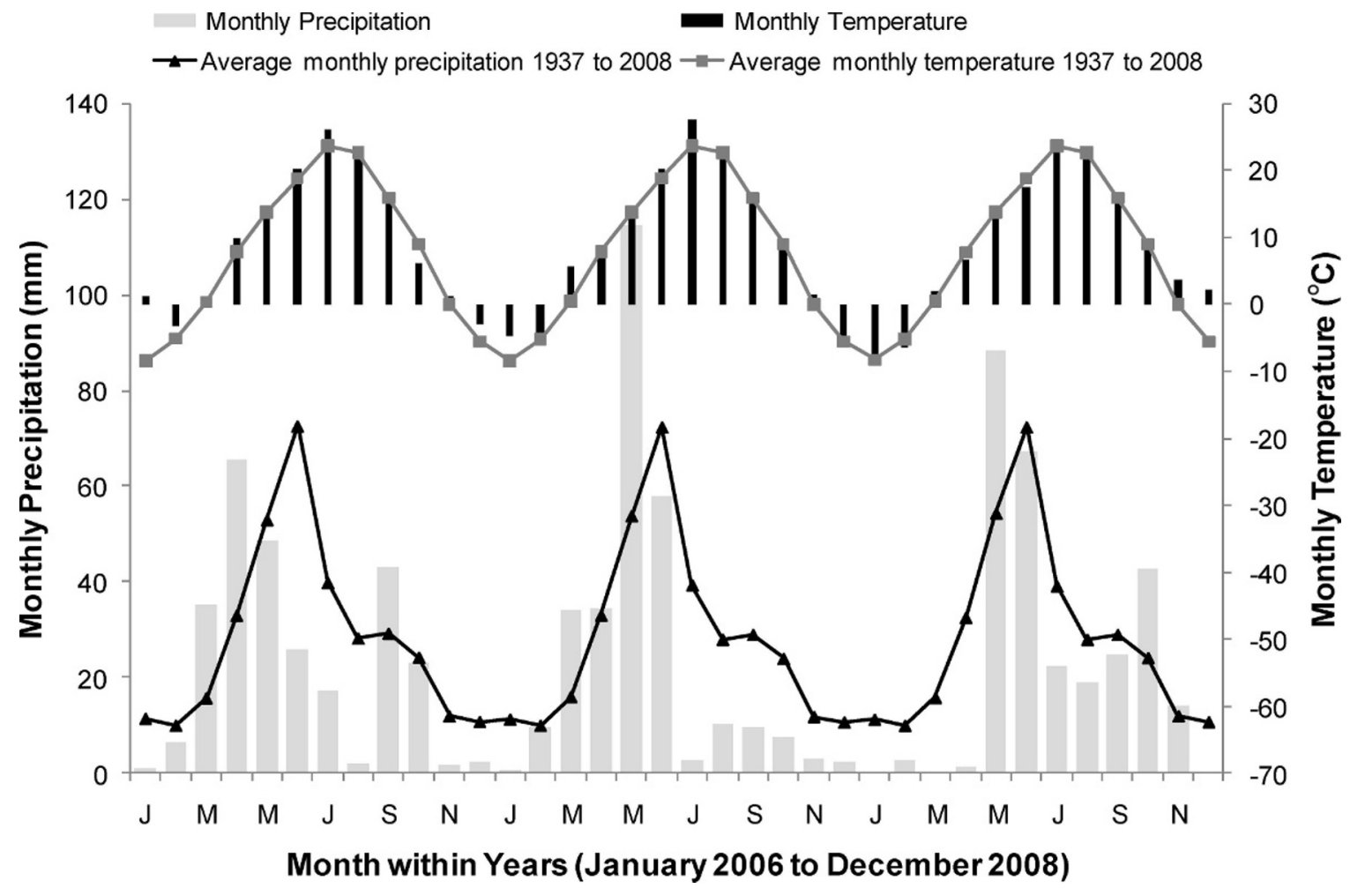

Figure 1. Monthly precipitation $(\mathrm{mm})$ and temperature $\left({ }^{\circ} \mathrm{C}\right)$ from January 2006 to December 2008 (bars) and their corresponding $72-y \mathrm{r}$ averages (lines; $\boldsymbol{\Delta}$ precipitation, $\square$ temperature) for Miles City, Montana, are provided. Annual precipitation was $271 \mathrm{~mm}, 286 \mathrm{~mm}$, and $282 \mathrm{~mm}$, respectively, for 2006, 2007, and 2008 with a 72-yr average annual precipitation of $340 \mathrm{~mm}$. Weather data were obtained from Western Regional Climate Center (WRCC 2009).

ground level from $0.25-\mathrm{m}^{2}$ quadrats within and outside of cages following grazing periods. Samples were dried to a consistent weight at $60^{\circ} \mathrm{C}$, then weighed to estimate utilization and plant production.

\section{Sample Collection and Analyses}

Ruminally cannulated ewes provided rumen extrusa diet samples to estimate and describe nutritional chemical composition of selected diets. Diet extrusa samples were collected on 4 June, 19 June, 6 July, and 24 July for spring; 6 July, 24 July, 14 August, and 28 August for early summer; and 14 August, 28 August, 20 September, and 10 October for late summer grazing trials in 2007 and on 29 May, 18 June, 2 July, and 23 July for spring; 3 July, 22 July, 13 August, and 26 August for early summer; and 14 August, 27 August, 19 September, and 8 October for late summer grazing trials in 2008 (Fig. 2). In 2008 ruminally cannulated ewes were removed at the same time as noncannulated ewes and held in an adjacent pasture. For the remaining prescribed sampling dates, ruminally cannulated ewes were moved to experimental pastures for a day of extrusa sampling and promptly returned to their adjacent pasture (Fig. 2).

On the day of extrusa sampling, ruminally cannulated ewes were gathered and ruminal contents were completely evacuated and stored in 19-L plastic buckets. Ruminal walls were spongedried to remove any residual moisture as described by Lesperance et al. (1960). Ewes were then released into experimental pastures and allowed to graze for 45-60 min. After the grazing bout, extrusa was removed from the rumen and thoroughly mixed. An aliquot was saved for analysis, and original ruminal contents were replaced.

Extrusa samples (one from each ewe) were frozen at $-20^{\circ} \mathrm{C}$, lyophilized, ground to pass a 1-mm screen, and stored until analysis for DM, organic matter (OM; Association of Official Analytical Chemists 1990), and neutral detergent fiber (NDF; Goering and Van Soest 1970) on an OM basis. Subsamples of ground extrusa were placed in glass, square-bottom vessels with metal rod inserts and dried in an oven at $60^{\circ} \mathrm{C}$ for $12 \mathrm{~h}$. Upon removal from a drying oven, vessels were capped with lids and subsequently placed on a roller grinder for $24 \mathrm{~h}$ (Mortenson 2003). Nitrogen was determined by combustion techniques using a C-N analyzer (CE Elantech, Inc., Lakewood, NJ). Nitrogen values were multiplied by 6.25 to obtain crude protein (CP) concentration, which was then expressed on an OM basis.

At 0700 hours on the day of in vitro analyses, rumen inoculum was collected from five ruminally cannulated ewes on alfalfa hay diets and placed directly into Dewar flasks (Nalgene 4150-200; StevenJo \& Steph, Rochester, NY) that had been incubated to $39^{\circ} \mathrm{C}$ for $24 \mathrm{~h}$. Samples were immediately transported to LARRL, and rumen boluses were strained through four layers of cheesecloth into a 6-L Erlenmeyer flask that had been prewarmed in a $39^{\circ} \mathrm{C}$ water bath under continuous exposure to $\mathrm{CO}_{2}$ gas. Next, $500 \mathrm{~mL}$ of rumen liquor was measured out into a graduated cylinder and was combined with $500 \mathrm{~mL}$ of phosphate buffer $\left(70.8 \% \mathrm{Na}_{2} \mathrm{HPO}_{4}\right.$ and $29.2 \% \mathrm{KH}_{2} \mathrm{PO}_{4}$; Menke et al. 1979) and $1000 \mathrm{~mL}$ of McDougal's buffer (Tilley and Terry 1963) already in vessels of 


\begin{tabular}{|c|c|c|c|c|c|c|c|}
\hline \multirow{2}{*}{$\begin{array}{c}1.5 \text { ha } \\
\text { Not } \\
\text { Used }\end{array}$} & \multicolumn{2}{|c|}{$\begin{array}{l}\text { Yr 1 } \\
\text { Spring }\end{array}$} & \multicolumn{2}{|c|}{$\begin{array}{c}\text { Yr } 1 \\
\text { Early Summer }\end{array}$} & \multirow{2}{*}{$\begin{array}{c}\text { Yr } 2 \\
\text { Early } \\
\text { Summer }\end{array}$} & $\begin{array}{l}\text { Yr } 2 \\
\text { Spring }\end{array}$ & $\begin{array}{c}\text { Yr } 2 \\
\text { Early Summer }\end{array}$ \\
\hline & \multicolumn{2}{|c|}{$\begin{array}{c}\text { Yr } 1 \\
\text { Late Summer }\end{array}$} & \multicolumn{2}{|c|}{ Not Used } & & $\begin{array}{c}\text { Yr } 2 \\
\text { Late Summer }\end{array}$ & $\begin{array}{l}\text { Yr } 2 \\
\text { Spring }\end{array}$ \\
\hline \multicolumn{2}{|c|}{$\begin{array}{l}\text { Yr } 1 \\
\text { Spring }\end{array}$} & \multicolumn{2}{|c|}{$\begin{array}{c}\text { Yr } 1 \\
\text { Early Summer }\end{array}$} & \multicolumn{2}{|c|}{$\begin{array}{c}\text { Yr } 1 \\
\text { Late Summer }\end{array}$} & $\begin{array}{l}\text { Yr } 2 \\
\text { Spring }\end{array}$ & $\begin{array}{c}\text { Yr } 2 \\
\text { Early Summer }\end{array}$ \\
\hline \multicolumn{2}{|c|}{$\begin{array}{c}\text { Yr } 1 \\
\text { Late Summer }\end{array}$} & \multicolumn{2}{|c|}{$\begin{array}{c}\text { Yr } 1 \\
\text { Early Summer }\end{array}$} & \multicolumn{2}{|c|}{$\begin{array}{l}\text { Yr 1 } \\
\text { Spring }\end{array}$} & $\begin{array}{c}\text { Yr } 2 \\
\text { Late Summer }\end{array}$ & $\begin{array}{c}\text { Yr } 2 \\
\text { Late Summer }\end{array}$ \\
\hline
\end{tabular}

\section{Grazing and Sampling Schedule}

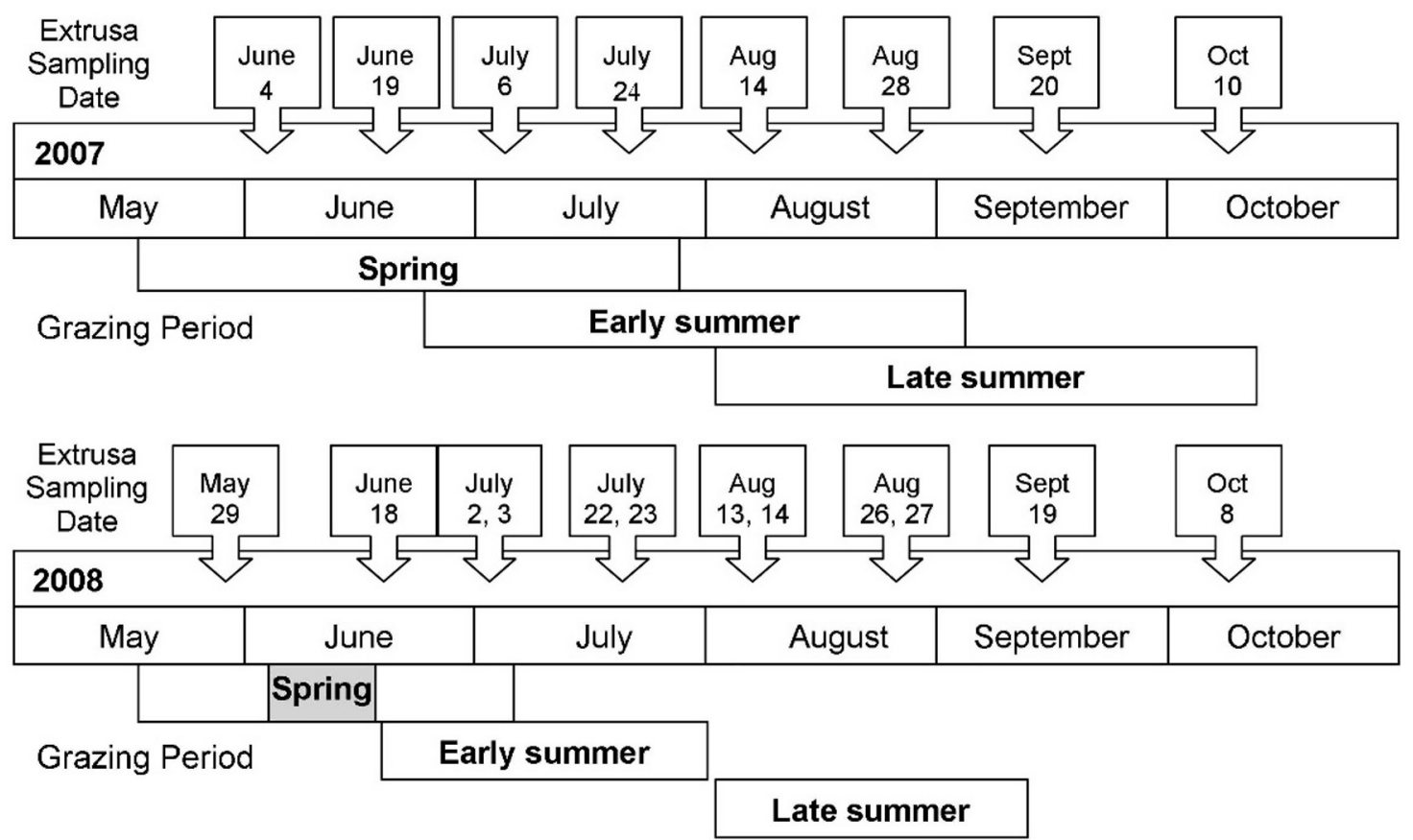

Figure 2. Description of randomization for pasture assignment for grazing period and year and outline of diet sampling and grazing period protocols used in both years. Shaded area for spring grazing period 2008 indicates when ewes were removed due to insufficient forage growth.

a DAISY ${ }^{\mathrm{II}}$ apparatus (ANKOM Technology Corp, Fairport, $\mathrm{NY})$ maintained at $39^{\circ} \mathrm{C}$. Vessels also contained duplicate samples (i.e., two duplicate sets of $250 \mathrm{mg}$ of sample $\cdot \mathrm{bag}^{-1}$ [F57; $5 \times 5.55 \mathrm{~cm}^{2}$; ANKOM Technology Corp]). Vessels were purged with $\mathrm{CO}_{2}$ for $30 \mathrm{~s}$, and a lid was secured onto the jar and immediately placed back into the DAISY ${ }^{\mathrm{II}}$ apparatus (process was repeated for each of four vessels).

Samples were subjected to in vitro incubation in the presence of ruminal inoculum for $48 \mathrm{~h}$ at $39^{\circ} \mathrm{C}$. At the end of $48 \mathrm{~h}$, incubation bags containing samples were removed and rinsed under reverse osmosis water until effluent was clear. Duplicate bags were placed into $\mathrm{ANKOM}^{220}$ Fiber Analyzer (ANKOM Technology Corp), and NDF disappearance was determined. Bags were dried at $60^{\circ} \mathrm{C}$ for $48 \mathrm{~h}$ to determine residual DM weights followed by placement into a muffle furnace at $550^{\circ} \mathrm{C}$ for $8 \mathrm{~h}$ to determine residual OM weights. In vitro NDF disappearance (IVNDFD) was calculated as the NDF (as a percent of $\mathrm{OM}$ ) that disappeared from the initial weight inserted into the bag. Subsequently, another duplicate set was ashed in a muffle furnace, following the 48-h incubation, at $550^{\circ} \mathrm{C}$ for $8 \mathrm{~h}$ for determination of in vitro $\mathrm{OM}$ disappearance (IVOMD). To estimate metabolizable energy (ME) of diets consumed, 48-h IVOMD was used to calculate ME. Conversion of IVOMD to digestible energy (DE) was accomplished using the formula of Rittenhouse et al. (1971): DE (Mcal $\left.\cdot \mathrm{kg}^{-1}\right)=0.039$ (\% IVOMD) -0.10 , and DE was converted to ME using the relationship provided by the National Research Council (NRC 2000): ME 
$\left(\right.$ Mcal $\left.\cdot \mathrm{kg}^{-1}\right)=\mathrm{DE} \quad\left(\mathrm{Mcal} \cdot \mathrm{kg}^{-1}\right) \times 0.82$. Concentrations in Mcal $\cdot \mathrm{kg}^{-1}$ were multiplied by a factor of 4.184 for final expression as $\mathrm{MJ} \cdot \mathrm{kg}^{-1}$.

\section{Statistical Analysis}

Forage quality data were analyzed using the MIXED procedure of SAS with pasture as the experimental unit. Year of study, grazing period (following deferment), and sampling day (within grazing period) and their interactions were included in the model. The REPEATED statement included sampling day, with pasture within year as the subject, and variance components were used as the covariance structure. When significant $(P \leq 0.05)$, main effect means were separated using LSMEANS. Mean separations were carried out using PDMIX800 (Saxton 1998).

Animal BW data were analyzed using the MIXED procedure of SAS (SAS Institute, Inc., Cary, NC) with pasture as the experimental unit. Year of study and grazing period (spring, early summer, and late summer) and their interactions were included in the model. The REPEATED statement included grazing period with pasture as the subject, and variance components were used as the covariance structure. Preplanned orthogonal contrasts were used to test the effects of grazing period. Animal average daily gain (ADG) data were analyzed using the MIXED procedure of SAS (SAS Institute, Inc.) with pasture as the experimental unit. Year of study and grazing period (spring, early summer, and late summer) and their interactions were included in the model. When significant $(P \leq 0.05)$, main effect means were separated using LSMEANS. Mean separations were carried out using PDMIX800 (Saxton 1998).

\section{RESULTS AND DISCUSSION}

\section{Climatic (Study Site) Conditions}

Monthly temperature and precipitation for 2006, 2007, and 2008, and a 72-yr average are presented in Figure 1. Growing season (April through June) temperatures were slightly warmer $(4 \%)$ in 2007 and cooler $(8 \%)$ in 2008 compared to historical averages. Fall and spring precipitation (October through June) following fire were 14\% (2007) greater and 29\% (2008) less than the historical average. Spring precipitation (April through June) was $62 \%$ greater in 2007 and $1 \%$ less than the historical average in 2008. Summer precipitation (July through September) was $58 \%(2007)$ greater and 35\% (2008) less than the historical average for the current experiment. However, $90 \%$ of annual forage production is generally produced by 1 July because of prevailing weather and dominance by cool-season perennial grasses in the region (Heitschmidt and Vermeire 2005). Total current-year production was 1239 and $763 \pm 45 \mathrm{~kg} \cdot \mathrm{ha}^{-1}$ respectively, in 2007 and 2008. Previous research at Fort Keogh LARRL has indicated that summer fire has neutral to positive effects on total grass production the year following summer fire (Vermeire et al. 2011). End of grazing period biomass did not differ $(P>0.77)$ between years at $303 \pm 25 \mathrm{~kg} \cdot \mathrm{ha}^{-1}$, but utilization was greater in $2007(76 \%)$ than 2008 (60\%).

\section{Forage (Diet) Quality}

Forage quality and quantity are the most important factors that influence domestic livestock production on rangelands. Extrusa

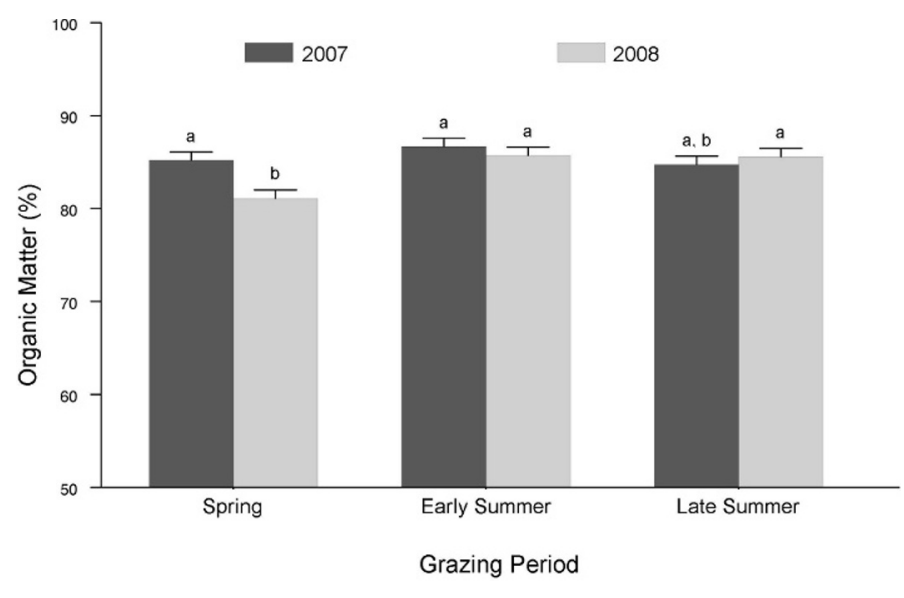

Figure 3. Least square means \pm standard error of the mean for year of study $\times$ grazing period (following deferment) for organic matter content (percent of dry matter; $P=0.03$ ) from extrusa samples collected from pastures subjected to summer fire the previous year. Means with different superscripts differ $(P<0.05)$.

OM (percent of DM) concentration varied by year of study and grazing period ( $P=0.03$; Fig. 3$)$. This interaction for extrusa OM most likely resulted from collecting extrusa samples following a precipitation event in 2008, which likely added some soil contamination to extrusa. Therefore, a reason to express forage characteristics on an OM basis is to account for any salivary or soil contamination on extrusa that may occur. OM concentrations (as a percentage of DM) did not differ $(P=0.93)$ by sampling day (within grazing period) and averaged $84.8 \pm 0.74 \%$.

As forages senesce, NDF concentrations typically increase while digestibility decreases. Extrusa NDF (on an OM basis) concentration varied by year, grazing period, and sampling day $(P<0.01$; Fig. 4). This interaction for extrusa NDF resulted from NDF concentrations in 2007 not being different across sampling dates and grazing periods, which was not different to what was observed in spring and early summer grazing periods in 2008. However, NDF concentration declined in 2008 during the last grazing period and sampling date to the lowest concentrations observed across both years, which may be a result of ewes being removed from grazing during this time period. NDF concentrations indicate that there was some young succulent vegetation available during the later portions of the late summer growing period. Others have reported periods of cool-season vegetative growth that led to improvements in forage quality that were not associated with the traditional April-June growing season (Adams and Short 1988; Grings et al. 2005; Waterman et al. 2007).

Similarly, extrusa CP (OM basis) concentration varied by year, grazing period, and sampling day $(P<0.01$; Fig. 5). Typically, as the growing season progresses, precipitation events diminish, temperatures increase, and the nutritional value of Northern Great Plains cool-season forages declines (Adams and Short 1988; Grings et al. 2005; Waterman et al. 2007). Extrusa CP concentrations numerically declined in 2007, but no statistical separation was measured. However, because of some late summer moisture in 2008 (Fig. 1), forage $\mathrm{CP}$ concentrations increased in extrusa samples and contributed to the interaction. This is concurrent with observations 


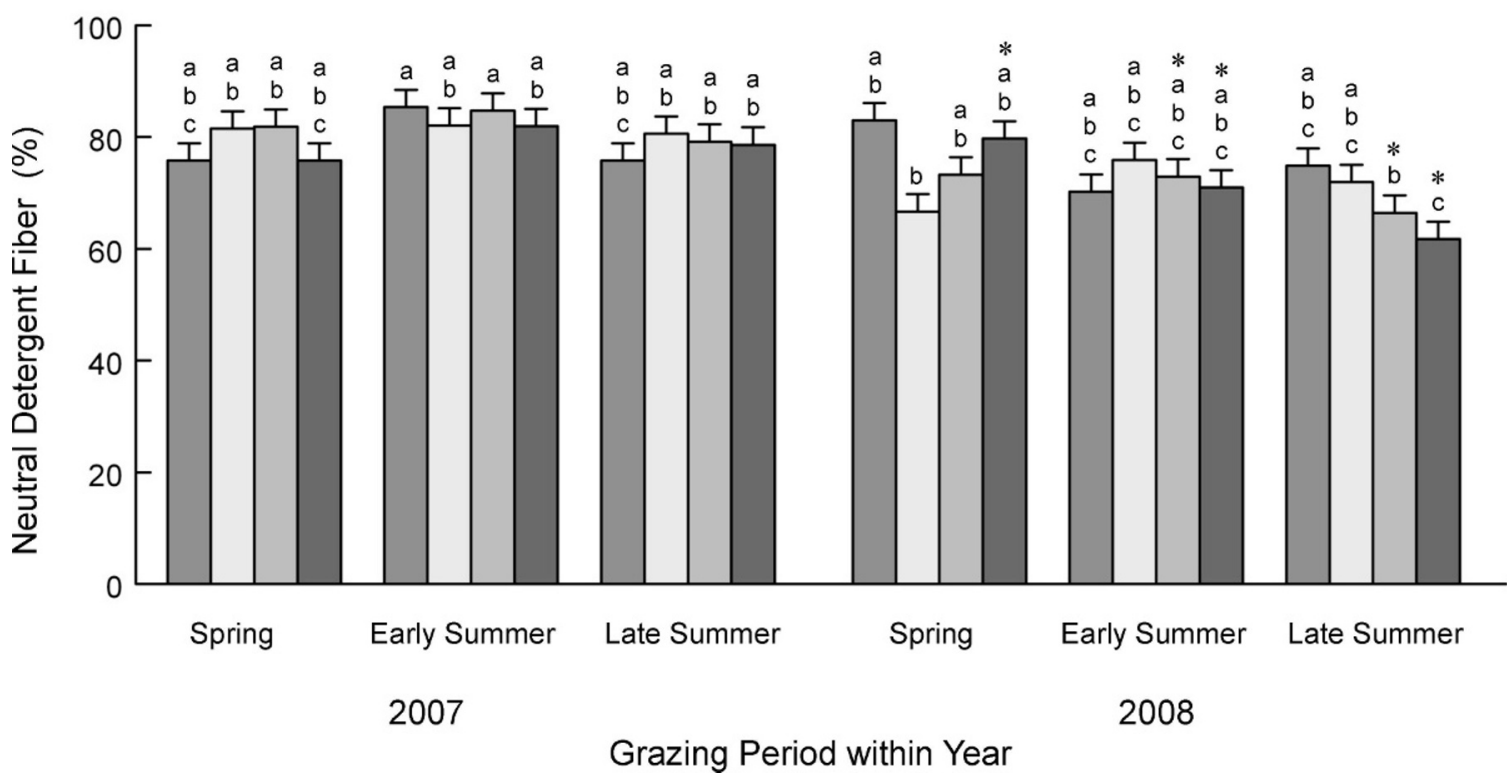

Figure 4. Least square means \pm standard error of the mean for year of study $\times$ grazing period (following deferment) $\times$ sampling day $($ within grazing period) for neutral detergent fiber (percent of organic matter; $P<0$. 01) from extrusa samples collected from pastures subjected to summer fire the previous year. Asterisks indicate sampling days that ewes were not grazing. Means with different superscripts differ $(P<0.05)$.

previously described for NDF concentrations. Additionally, fewer grazing days in 2008 potentially increased opportunities for ruminally cannulated ewes to select a higher quality diet during later sampling days. In order to obtain CP concentrations observed in the third and fourth sampling day of the late summer grazing period in 2008, young succulent vegetation must have been consumed. The generally high CP concentrations across grazing periods and sampling dates were not unexpected, as others have observed increased soil nitrogen availability (Wan et al. 2001) and forage nitrogen following fire
(Daubenmire 1968; Augustine and Milchunas 2009). It is important to recognize that ruminants have the ability to recycle nitrogen back into the rumen. However, the amount of nitrogen recycled in the 30-45-minute period in which diet extrusa collections took place would be negligible. Wallace et al. (1972) compared CP content in hand-clipped samples that were divided into two parts; one part was soaked in fresh saliva for $1.5 \mathrm{~h}$, and the second part was untreated with saliva. Their results determined that minimal saliva contamination occurred when samples were averaged across sampling dates for CP

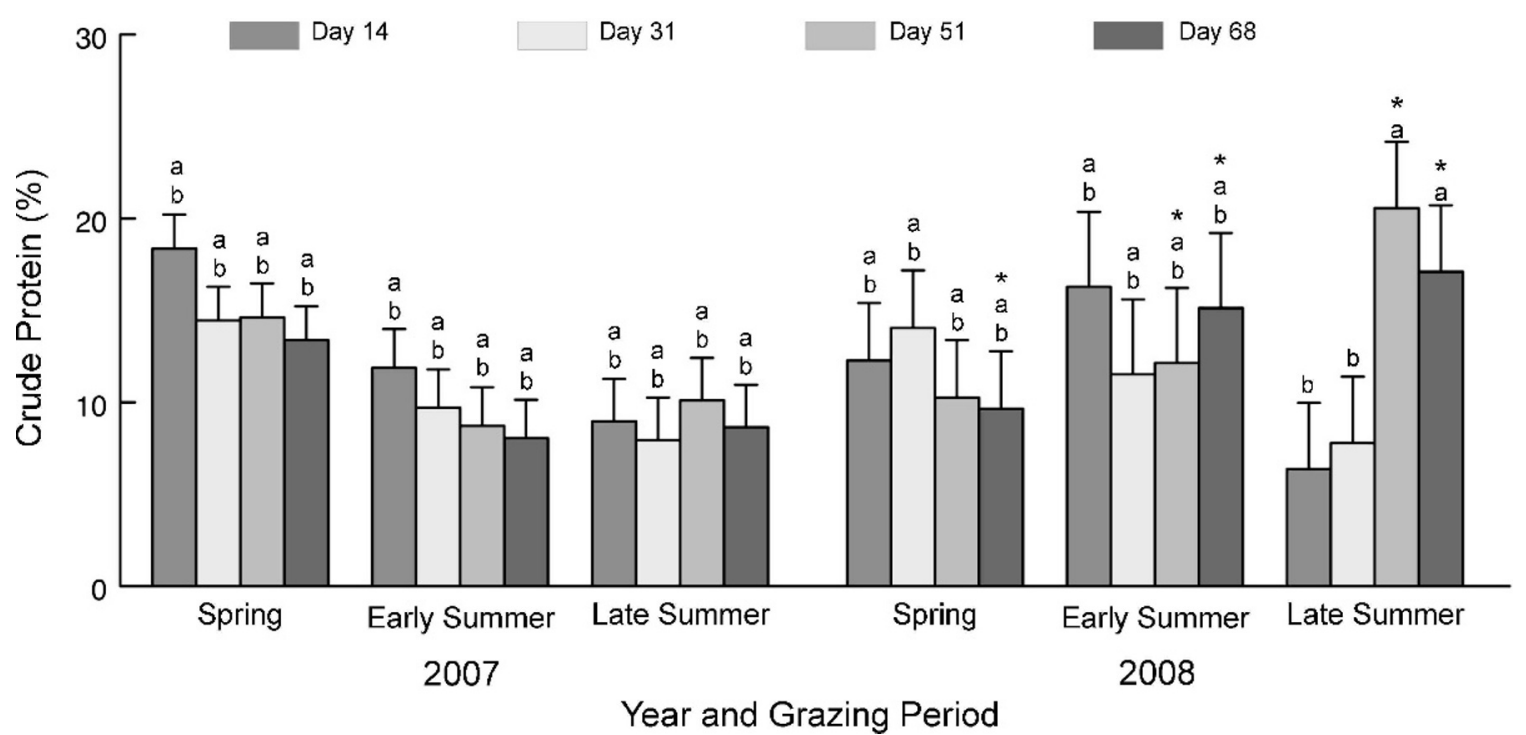

Figure 5. Least square means \pm standard error of the mean for year of study $\times$ grazing period (following deferment) $\times$ sampling day (within grazing period) for crude protein (percent of organic matter; $P<0.01$ ) from extrusa samples collected from pastures subjected to summer fire the previous year. Asterisks indicate sampling days that ewes were not grazing. Means with different superscripts differ $(P<0.05)$. 
Table 1. Least square means \pm standard error of the mean (SEM) for rumen diet extrusa measurements of in vitro organic matter (OM) disappearance (IVOMD) and metabolizable energy (ME) collected from pastures subjected to summer fire the previous year.

\begin{tabular}{|c|c|c|c|c|c|c|c|c|c|c|c|c|c|c|c|}
\hline \multirow[b]{2}{*}{ Item } & \multicolumn{2}{|c|}{ Year } & \multirow[b]{2}{*}{ SEM } & \multirow[b]{2}{*}{$P$} & \multicolumn{3}{|c|}{ Grazing period $^{1}$} & \multirow[b]{2}{*}{ SEM } & \multirow[b]{2}{*}{$P$} & \multicolumn{4}{|c|}{ Sampling day (within grazing period) } & \multirow[b]{2}{*}{ SEM } & \multirow[b]{2}{*}{$P$} \\
\hline & 2007 & 2008 & & & Spring & Early summer & Late summer & & & $14 \pm 0.87$ & $31 \pm 1.38$ & $51 \pm 1.34$ & $68 \pm 0.21$ & & \\
\hline IVOMD, \% & $61.7 a^{2}$ & $64.1 \mathrm{~b}$ & 0.74 & 0.03 & $62.9 \mathrm{ab}$ & $64.6 \mathrm{a}$ & $61.0 \mathrm{~b}$ & 0.90 & 0.03 & 63.1 & 63.8 & 61.8 & 62.7 & 1.04 & 0.60 \\
\hline ME & $7.91 \mathrm{a}$ & $8.23 \mathrm{~b}$ & 0.09 & 0.03 & $8.07 a b$ & $8.31 \mathrm{a}$ & $7.82 \mathrm{~b}$ & 0.12 & 0.02 & 8.11 & 8.19 & 7.93 & 8.04 & 0.14 & 0.59 \\
\hline
\end{tabular}

${ }^{1}$ Grazing period (following deferment).

${ }^{2}$ Main effect means within a row having different superscripts differ $(P<0.05)$.

concentrations (on an $\mathrm{OM}$ basis; $7.1 \%$ and $7.2 \% \mathrm{CP}$, respectively, for soaked and untreated hand-clipped samples). This confirms that negligible nitrogen contamination occurs when extrusa samples are collected from rumen cannulated animals. Furthermore, Lesperance et al. (1974) and Maryland and Lesperance (1977) indicate that keeping fistulated animals on similar forages minimizes contamination, and this protocol was implemented in this study.

Extrusa IVOMD is an estimate of forage energy availability and ruminal fermentability. Greater IVOMD indicates that the fiber concentration of forages (diet) being consumed by sheep grazing was more digestible than mature forage with a lower IVOMD. Digestibility decreases as rangeland forages senesce (Kartchner and Campbell 1979; Kirby and Parman 1986; Olson et al. 1994). In vitro OMD was greater $(P=0.03)$ in 2008 , which is consistent with having less biomass and most likely was a result of extrusa representing biomass at a younger stage of maturity. Regardless of year, IVOMD was lesser for late summer than early summer grazing periods and similar to the spring period $(P=0.03$; Table 1$)$. There were no differenc- es caused by sampling day $(P=0.60)$. Therefore, burning pastures in the late summer or early autumn and subsequently grazing these pastures the following year in the spring or early summer should allow for ewes to gain BW.

Extrusa IVNDFD is a measure of plant cell wall disappearance; the greater the IVNDFD, the more total NDF an animal has the potential to consume, which should support an improved rate of livestock production. Extrusa 48-h IVNDFD varied with year of study and sampling day $(P=0.01$; Fig. 6). In vitro NDFD decreased by 10.6 percentage units from early grazing to late grazing period in 2007 , whereas no differences were observed for IVNDFD in 2008 and were similar to those observed in 2007. Grazing period and sampling day also interacted $(P<0.01)$ in their effects on IVNDFD. The expected outcome is a gradual decline in IVNDFD as growing season progresses or as forages senesce. This was true for the spring periods; however, IVNDFD remained constant throughout the early and late summer grazing period (Fig. 6).

Calculated ME for extrusa samples was $0.32 \mathrm{MJ} \cdot \mathrm{kg}^{-1}$ greater $(P=0.04)$ in 2008 than 2007 (Table 1). In addition,

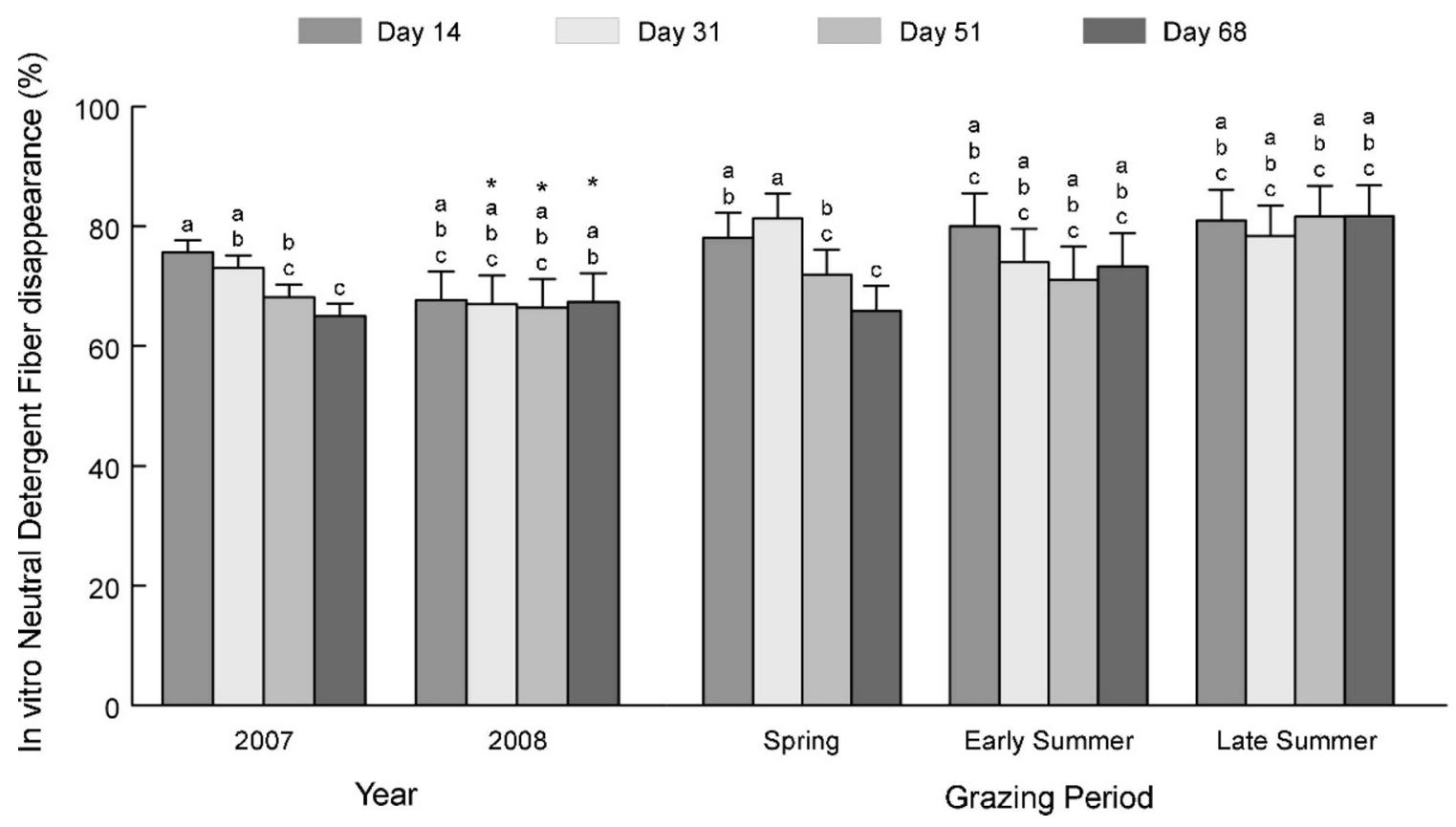

Figure 6. Least square means \pm standard error of the mean for year of study $\times$ sampling day (within grazing period), and grazing period (following deferment) $\times$ sampling day (within grazing period) for 48-h in vitro neutral detergent fiber disappearance (percent neutral detergent fiber on an organic matter basis; $P<0.01$ and $P<0.01$, respectively) from extrusa samples collected from pastures subjected to summer fire the previous year. Asterisks indicate sampling days that ewes were not grazing. Means with different superscripts differ $(P<0.05)$. 
regardless of year, ME in the early summer grazing period was greater than in the late summer grazing period but did not differ from the spring grazing period $(P=0.02$; Table 1$)$.

\section{Animal Performance}

On test ewe BW indicated that ewes started out heavier for late summer grazing than either the spring or early summer grazing periods in 2007, while in 2008 on test ewe BW was progressively greater from spring to early and late summer grazing periods $(P<0.01 ;$ Fig. 7$)$. This was anticipated because all ewes were the same age and allowed to grow on pasture until their introduction to assigned treatment pastures, which occurred at later dates. BW measures for off test BW were similar across grazing periods in 2007, while in 2008 off test $\mathrm{BW}$ measurements were greater for ewes in the early summer grazing period than either ewes grazing the spring or late summer periods $(P=0.05)$. ADGs varied by year and grazing period ( $P=0.03$; Fig. 7). However, patterns were similar each year, with ewe BW gains not differing between spring and early summer grazing periods compared to that of the late summer grazing period where negligible gains were observed (Table 2). Total gain $\left(\mathrm{kg} \cdot \mathrm{ha}^{-1}\right)$ was $10.9 \mathrm{~kg}$ greater $(P=0.01)$ in 2008 , and a quadratic $(P<0.01)$ response was measured for grazing period (Table 2). The quadratic response indicated that total gain declined as grazing period advanced from spring, to early summer, and late summer with a substantial decrease in total gain occurring in late summer. Furthermore, the greater BW gains for spring and summer periods for ewes in 2008 are most likely associated with the short grazing period and the ewes' ability to consume a diet that supported growth. Whereas in 2007 (longer grazing period) resulted in ewes having to select a diet of lower quality as forages matured with extended periods.

A mature ewe has an ME maintenance requirement of 4.6 MJ $\cdot \mathrm{d}^{-1}$ (NRC 1985) based on a BW of $50 \mathrm{~kg}$ and an ADG of $0.009 \mathrm{~kg} \cdot \mathrm{d}^{-1}$. Comparing this to the present study, the forage quality in the late summer grazing periods in combination with exposure to higher ambient temperatures experienced during this study might have prevented ewes from gaining BW. In other words, animals in the late summer grazing period may not have been able consume enough biomass to meet their maintenance requirements and thus lost BW. Others have observed similar temporal patterns in livestock performance on rangelands in the Northern Great Plains (Heitschmidt et al. 1993; Grings et al. 2004).

The apparent differences between diet quality and animal performance results can be attributed to the shortened ewe grazing periods in 2008 and continuation of the diet sampling protocol used in 2007 after ewes were removed from pastures in 2008. For spring-grazed pastures, all ewes in 2008 had been removed for $2 \mathrm{wk}$ and reintroduced $2 \mathrm{~d}$ before the second diet sampling day and then again all ewes were removed $2 \mathrm{wk}$ before the fourth diet sampling day with only ruminally cannulated ewes being reintroduced for the diet collection. The last two diet sampling dates for the 2008 early and late summer grazing periods also occurred after nonruminally cannulated ewes had been removed from pastures (i.e., residual biomass objective had been achieved so sheep were removed), but forage quality assessment continued to coincide with that collected in 2007. Therefore, when the ruminally cannulated
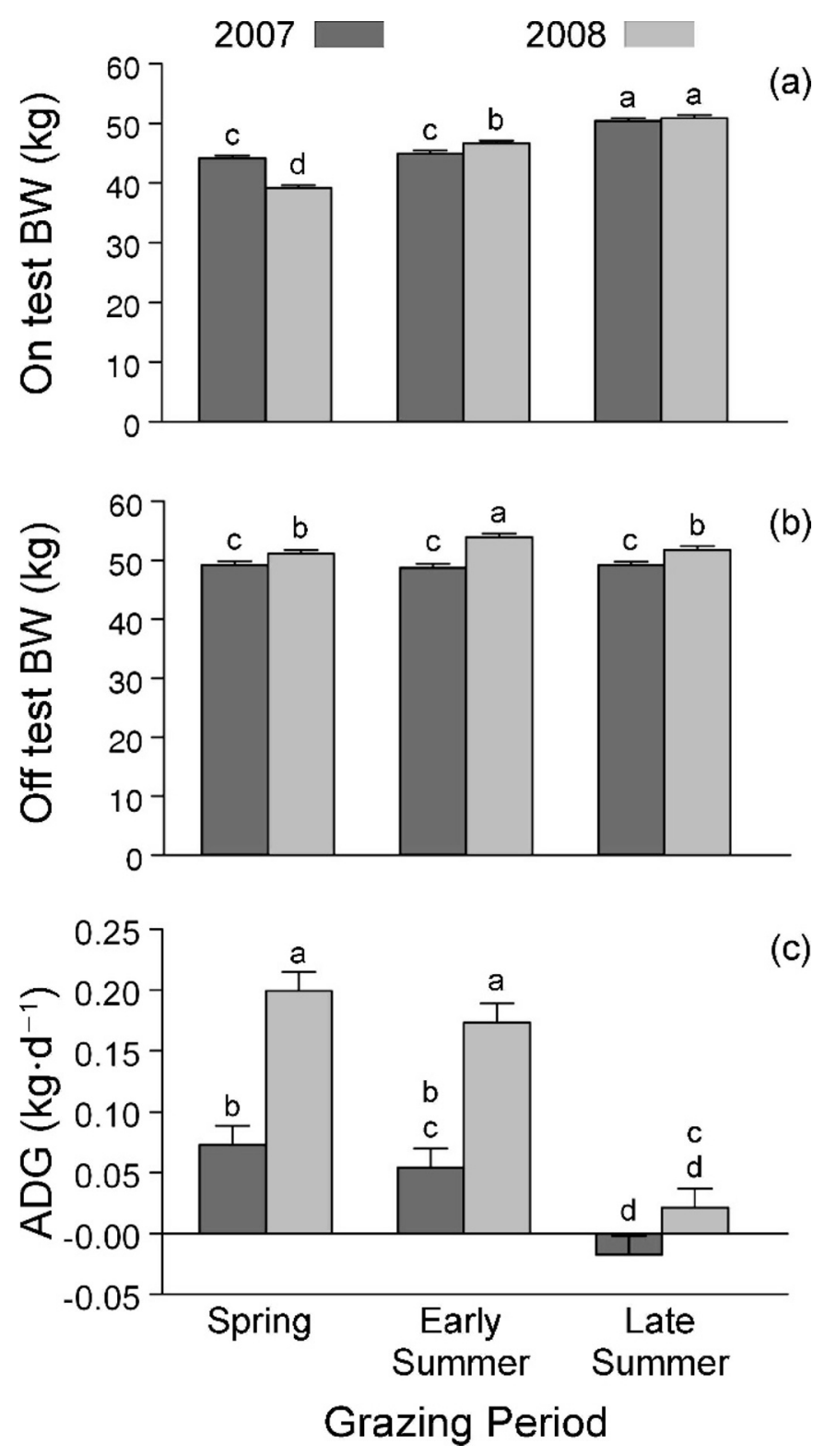

(c)

Figure 7. Least square means \pm standard error of the mean for year of study $\times$ grazing period (following deferment) for on test body weight (BW $[\mathrm{kg}] ; P<0.01)$, off test BW $(\mathrm{kg} ; P=0.05)$, and average daily gain (ADG; $\left.\mathrm{kg} \cdot \mathrm{d}^{-1} ; P=0.03\right)$ for ewes grazing pastures subjected to summer fire the previous year. Means with different superscripts differ $(P<0.05)$.

ewes were reintroduced to the pastures for these diet samples, they were able to select their diets from forages that had not been grazed for 1-4 wk. The effects of greater potential selection were particularly apparent for the spring and late summer grazing periods, with a sharp increase in diet CP on days 51 and 68 in late summer-grazed pastures (Fig. 5). We contend that diet selection of that quality would have been exhausted quickly or unavailable had the pastures been grazed continuously for the full period as observed in diet collections in 2007. During periods when noncannulated ewes were being evaluated for animal performance on pasture, diet CP followed a similar trend to that of 2007.

In conclusion, diet quality followed similar seasonal trends observed with unburned rangelands in the Northern Great 
Table 2. Least square means \pm standard error of the mean (SEM) for individual body weight $(\mathrm{BW}) \mathrm{gain}(\mathrm{kg})$ and pasture level $\mathrm{BW}$ gain $\left(\mathrm{kg} \cdot \mathrm{ha}{ }^{-1}\right)$ for ewes grazing pastures subjected to summer fire the previous year.

\begin{tabular}{|c|c|c|c|c|c|c|c|c|c|}
\hline \multirow[b]{2}{*}{ Item $^{1}$} & \multicolumn{2}{|c|}{ Year } & \multirow[b]{2}{*}{ SEM } & \multirow[b]{2}{*}{$P$} & \multicolumn{3}{|c|}{ Grazing period ${ }^{2}$} & \multirow[b]{2}{*}{ SEM } & \multirow[b]{2}{*}{$P$} \\
\hline & 2007 & 2008 & & & Spring & Early summer & Late summer & & \\
\hline BW Gain & $2.6 a^{3}$ & $5.3 \mathrm{~b}$ & 0.42 & 0.01 & $6.3 \mathrm{a}$ & $5.5 \mathrm{a}$ & $-0.2 b$ & 0.52 & $<0.01$ \\
\hline Gain $\cdot$ ha $^{-1}$ & $17.1 \mathrm{a}$ & $28.0 \mathrm{~b}$ & 2.61 & 0.01 & $36.8 \mathrm{a}$ & $32.5 \mathrm{a}$ & $-1.7 b$ & 3.19 & $<0.01$ \\
\hline
\end{tabular}

${ }^{1}$ Significant $(P<0.01)$ quadratic orthogonal estimates for grazing period.

${ }^{2}$ Grazing period (following deferment; mid-May for spring, mid-June for early summer, and early August for late summer).

${ }^{3}$ Main effect means within a row having different superscripts differ $(P<0.05)$.

Plains (Adams and Short 1988; Grings et al. 2005; Waterman et al. 2007). Compared to these studies on nonburned rangelands, our data suggest that forage nutritional value may be slightly improved by fire from the active growing season through periods when forages typically senesce and decline in nutritional value. However, ewe performance did not directly correspond with the observed diet quality, especially for the late summer grazing period. Although extrusa samples collected from ruminally cannulated ewes would suggest ewe performance should have been adequate to support BW gain, ewes maintained or lost BW during late summer and consistently gained weight in spring and early summer. Decisions about grazing management following summer fire should reflect a number of factors including forage availability, soil stability, and potential reductions in plant stress with deferred grazing. The reduced BW gains we observed indicate effects on animal performance should be accounted for in deferment decisions as well. These results along with ongoing research at Fort Keogh LARRL on plant community responses will aid in postfire grazing management decisions.

\section{MANAGEMENT IMPLICATIONS}

The present study was designed to evaluate the effects of grazing deferments on diet quality and ewe weight gain the year following summer fire on semi-arid rangeland. Our results confirmed that animals can perform well during the first grazing periods (spring and early summer) after summer fire. Our data also suggest that allowing animals to graze the spring following summer fire may increase risk because of a reduced ability to predict total forage availability early in the growing season and the increased potential for having to remove animals earlier than intended or allow overuse. Compared to nonburned sites, pastures grazed the year following summer burning have essentially no standing dead to support early grazing and litter content is minimal or absent. Therefore, grazing is completely reliant on postfire regrowth and should be monitored accordingly. Deferment until late summer resulted in minimal ewe growth or weight loss. Therefore, deferment until early summer may be preferable so that stocking rates can be more accurately determined and animal performance is not diminished.

\section{ACKNOWLEDGMENT}

The authors gratefully acknowledge Whisper Kelly, Susan Reil, Aaron Roth, and Cheryl Murphy for their technical assistance.

\section{LITERATURE CITED}

Adams, D. C., And R. E. Short. 1988. The role of animal nutrition on productivity in a range environment. In: R. S. White and R. E. Short [EDS.]. Achieving efficient use of rangeland resources. Miles City, MT, USA: Fort Keogh Research Symposium. p. 37-45.

Association of Official Analytical Chemists. 1990. Official methods of analysis. 15th ed. Arlington, VA, USA: AOAC. 38 p.

Augustine, D. J., and D. G. Milchunas. 2009. Vegetation respnses to prescribed burning of grazed shortgrass steppe. Rangeland Ecology \& Management 62:89-97.

Bureau of Land Management. 2007. Livestock management post-fire. In: Burned area emergency stabilization and rehabilitation handbook. BLM handbook H-17421. Washington, DC, USA: US Department of the Interior, Bureau of Land Management. p. 35-37.

Clarke, S. E., E. W. Tisdale, and N. A. Skoglund. 1943. The effects of climate and grazing on shortgrass prairie vegetation. Ottawa, Canada: Ministry of Agriculture, Canadian Dominion Department of Agriculture Technical Bulletin 46. 53 p.

Coupland, R. T. 1973. Producers: I. Dynamics of above-ground standing crop. Matador Project. Saskatoon, Canada: Canadian IBP Program Technical Report 27. $159 \mathrm{p}$

Daubenmire, R. 1968. Ecology of fire in grasslands. Advances in Ecological Research 5:209-266.

Dejong, E., and K. B. MacDonald. 1975. Soil-moisture regime under native grassland. Geoderma 14:207-221.

Goering, H. K., And P. J. Van Soest. 1970. Forage fiber analyses (apparatus, reagents, procedures, and some applications). Washington, DC, USA: USDAARS, Agriculture Handbook No. 379. 20 p.

Grings, E. E., R. E. Short, M. R. Haferkamp, and R. K. Heitschmidt. 2004. Late summer protein supplementation for yearling cattle. Journal of Range Management 57:358-364.

Grings, E. E., R. E. Short, K. D. Klement, T. W. Geary, M. D. MacNeil, M. R. Haferkamp, and R. K. Heitschmidt. 2005. Calving system and weaning age effects on cow and preweaning calf performance in the Northern Great Plains. Journal of Animal Science 83:2671-2683.

Heitschmidt, R. K., and L. T. Vermeire. 2005. An ecological and economic risk avoidance drought management decision support system. In: J. A. Milne [ED.]. Pastoral systems in marginal environments. XXth International Grasslands Congress; 26 June-1 July 2005; Dublin, Ireland. Wageningen, Netherlands: Wageningen Academic Publishers. 178 p.

Heitschmidt, R. K., J. D. Volesky, M. R. Haferkamp, and P. O. CurRie. 1993. Steer performance on native and modified Northern Great Plains rangeland. Journal of Range Management 46:529-533.

HIGGINS, K. F. 1984. Lightning fires in North Dakota grasslands and in pine-savanna lands of South Dakota and Montana. Journal of Range Management 37:100-103.

KartchneR, R. J., and C. M. Campbell. 1979. Intake and digestibility of range forage consumed by livestock. Bozeman, MT, USA: Montana Agricultural Experiment Station and US Department of Agriculture-Science Education AdministrationAgricultural Research, cooperating, Bulletin 718. 21 p.

KirBY, D. R., AND M. Parman. 1986. Botanical composition and diet quality of cattle under a short duration grazing system. Journal of Range Management 39:509-512. 
Lesperance, A. L., V. R. Bohman, and D. W. Marble. 1960. Development of techniques for evaluating grazed forage. Journal of Dairy Science 43:682689.

Lesperance, A. L., D. C. Clanton, A. B. Nelson, and C. B. Theurer. 1974. Factors affecting the apparent chemical composition of fistula samples. Reno, NV, USA: Western Regional Coordinating Committee 8, Nevada Agricultural Experiment Station. 30 p.

Maryland, H. F., and A. L. Lesperance. 1977. Mineral composition of rumen fistula samples compared to diet. Journal of Range Management 30:388-390.

Menke, K. H., L. Raab, A. Salewski, H. Steingass, D. Fritz, and W. Schneider. 1979. The estimation of the digestibility and metabolizable energy content of ruminant feeding stuffs from the gas production when they are incubated with rumen liquor. Journal of Agricultural Science 93:217-222.

Mortenson, M. C. 2003. Effects of interseeded alfalfa (Medicago sativa ssp. falcata) on forage production, forage quality, and carbon sequestration on a mixed-grass rangeland [thesis]. Laramie, WY, USA: University of Wyoming. $59 \mathrm{p}$.

[NRC] National Research Council. 1985. Nutritional requirments of sheep. 6th revised ed. Washington, DC, USA: National Academies Press. 99 p.

[NRC] National Research Council. 2000. Nutrient requirements of beef cattle. 7th revised ed. Washington, DC, USA: National Academies Press. 234 p.

Olson, K. C., J. S. Caton, D. R. Kirby, and P. L. Norton. 1994. Influence of yeast culture supplementation and advancing season on steers grazing mixed-grass prairie in the Northern Great Plains: I. Dietary composition, intake, and in situ nutrient disappearance. Journal of Animal Science 72:2149-2157.

Rittenhouse, L. R., C. L. Streeter, and D. C. Clanton. 1971. Estimating digestible energy from digestible dry and organic matter in diets of grazing cattle. Journal of Range Management 24:73-75.

Saxton, A. M. 1998. A macro for converting mean separation output to letter groupings in Proc Mixed. In: Proc. 23rd SAS Users Group Int. Cary, NC, USA: SAS Institute, Inc. p. 1243-1246.
Schmidt, K. M., J. P. Menakis, C. C. Hardy, W. J. Hann, and D. L. Bunnell. 2002. Development of coarse-scale spatial data for wildland fire and fuel management. Fort Collins, CO, USA: US Department of Agriculture, Forest Service, Rocky Mountain Research Station, General Technical Report RMRSGTR-87. $41 \mathrm{p}$.

Tilley, J. M. A., and R. A. Terry. 1963. A two stage technique for the in vitro digestion of forage crops. Journal of the British Grassland Society 18:104-111.

Vallentine, J. F. 1990. Grazing management. San Diego, CA, USA: Academic Press, Inc. 533 p.

Vermeire, L. T., J. L. Crowder, and D. B. Wester. 2011. Plant community and soil environment response to summer fire in the northern Great Plains. Rangeland Ecology \& Management 64:37-46.

Wallace, J. D., D. N. Hyder, and G. M. Van Dyne. 1972. Salivary contamination of forage selected by esphageal fistulated steers grazing sandhill grassland. Journal of Range Management 25:184-187.

Wan, S., D. HuI, AND Y. Luo. 2001. Fire efects on nitrogen pools and dynamics in terrestrial ecosystems: a meta-analysis. Ecological Applications 11:13491365.

Waterman, R. C., E. E. Grings, T. W. Geary, A. J. Roberts, L. J. Alexander, and M. D. MAcNelL. 2007. Influence of seasonal forage quality on glucose kinetics of young beef cows. Journal of Animal Science 85:2582-2595.

Westerling, A. L., A. Gershunov, T. J. Brown, D. R. Cayan, and M. D. Dittinger. 2003. Climate and wildfire in the western United States. Bulletin of the American Meteorological Society 84:595-604.

White, R. S., and P. O. Currie. 1983. Prescribed burning in the Northern Great Plains: yield and cover responses of 3 forage species in the mixed grass prairie. Journal of Range Management 36:179-183.

[WRCC] Western Regional Climate Center. 2009. Western Regional Climate Center. Western US climate historical summaries. Available at: http://www.wrcc.dri. edu/climsum.html. Accessed 1 March 2009. 